\title{
Innovation in Circumpolar Regions: New Challenges for Smart Specialization
}

\author{
Adrian Healy \\ Cardiff University
}

\begin{abstract}
Smart Specialization has emerged as a novel policy approach for stimulating regional innovation in the European Union. It advocates that regions should focus their innovation support on those activities where they possess a regional comparative advantage, in order to develop sufficient critical mass to be globally competitive. The approach is not without its critics, both conceptually and in its practical implementation. This article explores the extent to which a smart specialization approach might be appropriate in remote circumpolar regions, and what lessons the concept can itself learn from such regions. Drawing on examples from three regions-Arjeplog (Sweden), Svalbard (Norway), and the Yukon (Canada) - the article suggests that the smart specialization approach has much to offer but that the approach would be strengthened through incorporating the particularities of innovation in the Circumpolar North.
\end{abstract}

The Northern Review 45 (2017): 11-32 


\section{Introduction}

The challenging economic context for remote and peripheral regions is well documented. Distant from major centres of population and with a limited industrial base, many regions struggle to support thriving economies, which results in reduced levels of prosperity, restricted access to services, and the out-migration of population. For circumpolar regions, which are here taken to include both those in the Arctic and the immediate Subarctic, the challenge is many times greater. Not only are accessibility costs that much higher and population levels, both of people and firms, that much sparser, but such regions also have significant climatic and environmental challenges to navigate (Larson and Fondahl, 2015).

Whilst most communities in circumpolar regions maintain their viability and, in many cases, are relatively prosperous, they tend to be dependent on the twin pillars of exploitation of natural resource endowments coupled with a substantial public sector heavily reliant on transfer payments (Drache, 2009; Duhaime and Caron, 2015; Riabova, 2010). The dominant logic of such economies tend to the extractavist, which can stifle the ability of communities and governance institutions to imagine alternative futures (Wilson and Stammer, 2016). As Wilson and Stammer recognize, however, the reliance on extractive industries leaves the economy susceptible to the vagaries of global commodity markets, vulnerable to changing tastes and preferences, and disposed to fluctuating economic fortunes.

The focus on the dominant extractive industries in circumpolar regions has meant that the rising contribution of what Petrov describes as "other" or "non-pillar" economies has been somewhat overlooked. Partly defined by what they are not, these "other" economies include knowledge based industries such as professional and technical services, arts and crafts, small-case custom manufacturing, recreation, and other activities (Petrov, 2015; 2016). Not only do these other economies tend to have stronger internal linkages and local multiplier effects, Petrov argues, but their rate of growth has been stronger than the "pillar" economies in recent years along with higher levels of productivity. In a related vein, Larsen (2016) contends that circumpolar economies are witnessing a period of diversification and transformation made possible by the advent of modern technology and communications networks, leading to stronger connections to the global economy. 
Petrov (2016) proposes that the role of the knowledge economy should move closer to the forefront of economic analysis in circumpolar regions and of strategizing for sustainable development in the Arctic. Reporting on the case of Alaska, he notes how many smaller places form visible hubs of innovation activity, albeit often highly specialized (Petrov, 2015). However, he also recognizes that the innovation system of the Arctic is relatively thin, with low levels of entrepreneurial activity, acknowledging that "the Arctic knowledge economy is characterised by the key role of individual inventor or single industry (and) connectedness to external networks vis-a-vis weak links within the Arctic" (Petrov, 2016, p. 51).

Strengthening the innovation performance of an economy is now widely promoted as a means of underpinning economic growth and higher-quality employment opportunities. This draws on academic and policy experience from across the world that now stresses the importance of both innovation and the role of the regional innovation environment, or ecosystem, in creating a nurturing environment (Drache, 2009; Morgan and Nauwelaers, 1999; De Bruijn and Lagendijk, 2005; Wolfe, 2014). In the European Union (EU), this evolution of policy has most recently culminated in the promotion of "Research and Innovation Strategies for Smart Specialization" (RIS3) across the whole of the EU (Foray et al., 2011; Foray, 2014).

The concept of smart specialization has been a response to the observation that many regions simply seek to imitate the innovation practices of more advanced regions, seeking to transplant hightechnology activities with insufficient thought given to the particularities of the local context. Rather than reproducing mimetic strategies, the smart specialization approach argues that regions, or nations, should focus on those activities in which they have a comparative advantage. In doing so, they should be led by an entrepreneurial discovery process, rather than political selection or the continuation of historic legacies.

Yet the innovation challenges for peripheral regions, and those regions with less developed research and innovation systems, has led some to question the appropriateness of this approach to these places (Cooke, 2012; Torre and Wallet, 2013). They suggest that an approach that may be appropriate in regions with advanced research and innovation systems is ill-equipped to deal with the challenges of less-innovative regions. For Wolfe (2009) and Overman (2012) the innovation agenda is also fundamentally an urban agenda, raising questions as to its appropriation for sparsely populated circumpolar regions. In a further riposte to the smart specialization approach, Nathan and Overman (2013) also question the 
significance attached to clustering and innovation in the growth literature, preferring instead to highlight the role of agglomeration economies, the availability of skilled labour, and the role of horizontal policy instruments.

In the EU, the smart specialization approach now forms a basis for regional policy across the Union, including in circumpolar regions. It is thus pertinent to examine the relative merits of such an approach in circumpolar regions more generally, where our understanding of circumpolar innovation is in its infancy (Coates and Poelzer, n.d). Drawing on the underlying principles of smart specialization, along with a number of practical examples, this article examines the relevance of the smart specialization approach for circumpolar regions and assesses whether it might form the basis of a new approach to economic development in the Arctic. The article argues that, with the appropriate consideration, the approach has much to offer, whilst highlighting that our understanding of the nature and purpose of the innovation process may need some modification.

\section{The Challenge of Innovation in Circumpolar Regions}

Whilst a strict definition of "circumpolar" refers only to areas surrounding the earth's poles, in practice it is often used more loosely to refer to Arctic and Subarctic regions with similar climatic or environmental characteristics. In the northern hemisphere this covers a broad sweep of territory, from the north of Scandinavia and Russia through the northern territories of Canada and Alaska. The scale of the area and the diversity of contexts and institutions makes it difficult to generalize about the circumpolar, although there are a number of common features (Baerenholdt \& Aarsaether, 2002).

Typically, economic activity in circumpolar regions is dependent on natural resource exploitation and on the support of the state including redistributive subsidies. The challenges to developing more diversified economies are well known. Communities are often small and can be widely dispersed, limiting the available labour force; and firms tend to be small, limiting local employment opportunities, or branches of large conglomerations. Local markets are consequently restricted, with firms dependent on small-scale production or needing to access international trade opportunities. Access to higher skilled workers is limited, and outmigration of the population is a common theme. Transport costs tend to be high, with extended supply chains, elevated energy costs, and punishing infrastructures. More extreme climates and fragile environmental conditions further accentuate these challenges. 
Whilst economic diversification has been occurring in many circumpolar regions, this is also often dependent on the development of the region's natural resource base, such as in the rise of tourism in various forms. Similarly, other opportunities are identified in the exploitation of bio-based cold-water marine resources or oil and gas reserves. With the warming of the Arctic, development of these resources may become more viable, particularly as circumpolar transport routes open further (Milazzo, n.d). The challenge for writers such as Coates and Poelzer (n.d) is to develop the innovation in circumpolar regions that might stimulate higher levels of endogenous growth and a transformation of economic opportunities (see also Doloreux, 2003; Doloreux \& Dionne, 2008). However, as Coates and Poelzer identify, circumpolar innovation remains in its infancy.

Our understanding of regional innovation systems has developed substantially over the past twenty years. There is now a strong literature on the characteristics of innovative regions, as well as those that are less developed. Typically, circumpolar regions can be seen to lack many of the assets that are regarded as underpinning effective regional innovation systems. These may include the absence of a critical mass of innovative firms alongside a limited presence of key organizations such as universities and other research actors or financial institutions (Trippl et al., 2016). Low levels of clustering, combined with long travel times between places, also limits the extent to which different forms of proximity are able to stimulate and strengthen knowledge exchange as part of the innovation process (see for example Gertler, 2008). The role of institutions is also now recognized as underpinning regional innovation performance (Rodriguez-Pose, 2013), with Trippl et al. (2016) suggesting that regions with poor institutional qualities tend to have poorer levels of innovation performance. Huskey (2005) suggests that in the case of the polar North, poorer institutional capacities are also associated with their remoteness. Resource-rich economies, such as are to be found in circumpolar regions, often fail to translate their economic benefits into long-term growth, although whether the reasons for this are due to the quality of the institutions is disputed (see Mehlum et al., 2005). One component of this is the limited extent to which circumpolar research is supported by national governments, but also the lack of coordination, collaboration, and sense of community of (relatively small) research actors working in this field (Iskanius, n.d).

However, it may be that in the case of circumpolar regions we are looking for innovation in the wrong places, taking an approach developed in advanced economies in core regions and mistakenly seeking to 
replicate this in more peripheral regions such as circumpolar territories. Much of our understanding of innovation processes is based on a specific perspective that is dominated by the analytical knowledge base of science and technology. As Asheim and colleagues indicate, innovation can also occur through other knowledge bases, particularly those that are based on synthetic (typically engineering) or symbolic (such as design) knowledge (Asheim \& Gertler, 2005; Asheim et al., 2007). Indigenous knowledge systems can also inform the innovation process in ways that are only gradually being recognized.

It is also the case that the research that takes place in circumpolar regions is often about these places, rather than for these places. This is exemplified in descriptions of the North as a "laboratory for scientific research" (Heinen, 2005, p. 91), echoing an earlier concern expressed by Kaul (2002). Kaul argues that a change in perspective may be required if development in the Arctic is to be more sustainable and people centred. Current perspectives emphasize external ambitions and focus on what the Arctic can provide to the scientific community as a whole, rather than linking this to the needs and resources of Arctic communities. Strengthening the insider's perspective may be a starting point to a more applicable approach to innovation in circumpolar regions.

\section{The Smart Specialization Approach}

The concept of smart specialization was first elaborated in 2008 and has risen rapidly to become an underpinning foundation of regional innovation policy in the EU (Foray et al., 2011; Foray, 2014; Kroll, 2015). Smart specialization itself is based on the notion that authorities should identify selective knowledge "domains," or priorities, in areas where a region (or a State) has a comparative advantage (Foray, 2014; European Commission, 2012). This emphasizes the need for policy makers to make choices as to which technologies or sectors should be supported through public policies. By making choices, it is argued, one can realize scale economies, through achieving critical mass, and develop distinctive paths based on areas of competitive advantage. A focus on areas of comparative strength also guards against the tendency to develop mimetic strategies, which has characterized regional innovation policy making in recent years. These choices should then be set out in a Research and Innovation Strategy for Smart Specialization (RIS3).

Drawing on work by Hausmann and Rodrik (2003), Foray and colleagues argue that, at its heart, smart specialization has to be built on an entrepreneurial discovery process undertaken by firms and other 
organizations operating in the economy (Foray et al., 2011). This recognizes that the public sector is insufficiently informed to identify those areas of comparative strength on its own, but needs to harness the knowledge of businesses and other actors. For Hausmann and Rodrik, the entrepreneurial discovery process is a process of self-discovery whereby firms identify what can, and cannot, be produced competitively at a particular time or place. In this regard, the entrepreneurial discovery process is one of trial and error, of success and, importantly, of failure (Hausmann \& Rodrik, 2003). This builds on the ideas of Hayek (1978), in that entrepreneurial discovery involves firms becoming aware of opportunities that were not previously visible. Kirzner (1997) argues that this takes us beyond simple notions of imperfect information as it suggests that some opportunities are simply unknown until they are tried and tested.

In the context of the smart specialization approach, the entrepreneurial discovery process has, to date, largely related to the identification of the domains to be set out in the RIS3. As Kroll (2015b) notes, the European Commission has neither the "mandate nor the capacity" to identify regional specializations itself and so the onus is placed on regional or national governments to do so through a "bottom-up" process of entrepreneurial discovery, drawing on the knowledge of local firms, knowledge institutions, and public actors. For some, the state should play an active role in the discovery process itself (Mazzucato, 2013), but in most of the smart specialization literature to date the emphasis has been on designing a process to identify those economic domains where regions (or member states) believe that they have the potential to obtain a comparative advantage (Boden et al., 2015). The aim of this process is to effect a transformational change that will guide an economy away from modes of path extension towards path creation and path renewal (Tödling \& Trippl, 2005, 2013) or, as Morgan (2016) puts it, "building on the past whilst breaking with the past."

To achieve this transformational agenda, the European Commission argues that the RIS3 should consider four general principles known as the four "Cs" (European Commission, 2012, p. 17):

- (Tough) Choices and Critical Mass

- Competitive Advantage

- Connectivity and Clusters

- Collaborative Leadership. 
In doing so, the Commission proposes some simple steps in the design of a RIS3, namely: Analyzing the regional context and potential for innovation; setting up a sound and inclusive governance structure; producing a shared vision about the future of the region; selecting a limited number of priorities for regional development; establishing suitable policy mixes; and integrating the monitoring and evaluation mechanisms (European Commission, 2012). In undertaking the analysis of the regional context and potential for innovation, the Commission stresses that this should be an asset based strategy that incorporates three key elements (European Commission, 2012, p. 18):

- an analysis of regional/national assets (technological infrastructure)

- entrepreneurial dynamics

- outward dimensions.

The development of an RIS3, at either a national or regional scale, is a condition for eligibility for support under the European Regional Development Fund (ERDF) of the European Union's Cohesion Policy for the period 2014-20 (European Commission, 2013). This is a strong requirement, as the EU's cohesion policy is a substantial policy instrument with a budget of some 350 billion euros for 2014-20. This mandatory requirement has generated a robust debate regarding the appropriateness of the approach to stimulating innovation performance, particularly the implications of this for different types of regions in the EU, as well as the implementation of the concept in practice (Cooke, 2012; Foray, 2014).

The RIS3 approach also owes much to the heritage of regional innovation systems thinking that has been a foundation for the evolution of regional economic development policy over the past twenty-five years (Cooke, 2001; Asheim \& Gertler, 2005). In line with this legacy, a key feature of the RIS3 approach is its territorial focus. The European Commission explicitly describes Research and Innovation Strategies for Smart Specialization (RIS3) as "integrated, place-based economic transformation agendas" (European Commission, 2014a), highlighting their role in the restructuring of the European economic landscape and responding to the EU's support for place-based development (Barca, 2009). In a development from previous practices that emphasized the regional dimension, however, the RIS3 approach allows for the conditionality to be met at either a national or a regional scale. In practice this has led to a variegated approach, with some member states submitting national strategies, some regional strategies, and others a mixture of both. 
The adoption of RIS3 is not without its critics, both of the concept and its implementation (Cooke, 2012). As Foray and colleagues themselves acknowledge, there seems to be a growing gap between the policy practice and the theory (Foray et al. 2011). Criticisms fall into three main camps-First, the apparent emphasis on innovation led by science and technology, with a focus on high-tech sectors and a lack of attention to alternative models of innovation focused on Doing, Using, and Interacting (DUI)(Cooke, 2012); second, a traditional framing of priorities alongside a watering down of selected priority choices to more general categorizations (Iacobucci, 2014, McCann \& Ortega-Argilés, 2011) with a continuing stress on imitative innovation (Capello \& Lenzi, 2013); and, third, is the apparent treatment of all regions as equivalent (Torre \& Wallet, 2013). For many, it is difficult to shake off the idea that the concept of smart specialization is more appropriate to the development of regions with established research and innovation systems, rather than less developed regions ${ }^{1}$ or those with less developed research and innovation systems.

Regions with less developed research and innovation systems offer a valuable test bed for the RIS3 concept as they are, arguably, the most challenging environment in which to develop innovation support policies yet can be those most in need of such policies (see Oughton et al., 2002 regarding this paradox). Such regions are typically confronted by organizational thinness; lock-in to declining sectors and out-dated technologies; fragmented systems that inhibit networking and knowledge exchange; and a weak capacity to drive transformative change (Tödling and Trippl, 2005; Strambach and Klement, 2012; Weber and Rohracher, 2012). Exploring the concept of smart specialization in such contexts offers an opportunity to examine what lessons the concept can learn from these regions and the extent to which a smart specialization approach might be appropriate as a tool for promoting transformational change in these places.

\section{Innovation Practices in Circumpolar Regions}

Across the Circumpolar North the assets and practices for innovation vary significantly. The following section briefly introduces examples of innovation practices in three circumpolar regions. These are chosen to highlight some common features that can inform our understanding of the potential for adopting a smart specialization approach in these regions, and the lessons that might, in turn, inform the development of the concept of smart specialization. An analysis of the common lessons that can be drawn concludes the section. 


\subsection{Northern Sweden}

Since the early 1970s, Arjeplog, located $61 \mathrm{~km}$ south of the Arctic Circle in Norrbotten County, Sweden, has developed its reputation as an extremeweather testing centre for the world's leading car makers. Consistent cold temperatures ensure that local lakes maintain a thickness of ice that is suitable for test driving, and the sparse population restricts the opportunities for novel ideas to be publicized before the companies are ready. Equally, the presence of a robust and high quality infrastructure network, the legacy of the timber and mining industries, and high levels of public investment, provide a strong foundation for testing and for accessibility. Each winter, companies that include BMW, MercedesBenz, Audi, Toyota Motors, General Motors, Ford, Fiat, Peugeot, Saab, and Hyundai temporarily locate up to 9,000 personnel to the area, with almost 3,000 engineers working there on any one day, almost doubling the resident population of around 4,000 (Kinnander, 2011). These companies are served by local service providers, some of which have now emerged as major companies in their own right.

The rise of car testing began when Bosch used the area to test an antilock brake system, having gained permission to land heavy aircraft on one of the lakes. It was soon followed by Opel, Mercedes, Volkswagen, and Porsche, which all began testing their cars in the area. The initial evolution of the cluster was highly organic with very little involvement of the public sector and limited dialogue with the municipality. As the industry has developed, so the involvement of the municipality has increased with ongoing support for land and infrastructure investments amongst other actions. The development of automotive testing facilities has helped transform the economy and offset the effects of a decline in the traditional timber industry and the closure of the local lead mine in 2001. The industry now supports around 500 local jobs, and contributes some 700 million kronor (CAD \$108 million) to the region's economy (Kinnander, 2011). In a sign of the maturity of the industry, service providers from Arjeplog are now investing in service testing facilities in Greenland and in northern China (Sölvell, 2016).

In contrast to the entrepreneurial emergence of car testing in Arjeplog, the nearby town of Luleå provides an example of where a cold climate has been mobilized by the state in seeking to attract a major inward investment. It is here that Facebook will develop its first data centre to be located outside of the United States, on the Aurorum Science Park adjacent to the local university and on the outskirts of Luleå. A cold climate provides 
significant cost savings to data centres that have to expend energy to dissipate the heat generated by their massive arrays of data servers. Other attractors were the good Internet connectivity, through an extensive fibre-optic network, and guaranteed access to a reliable power network (Orange, 2012; Gregory, 2013). That the area was able to guarantee the availability of power supplies, through two grid systems, is a legacy of its industrial past where the local iron, steel, and paper industry also required access to extensive power supplies. The demise of these industries has left significant levels of redundant capacity, which Facebook has been able to exploit.

Geological and political stability, together with the availability of cheap, and renewable, energy through hydroelectric power, were also regarded as locational advantages favouring Luleå over other competitors. The investment also benefitted from around 10 million euros of support from the European Regional Development Fund, which was reported to be a factor in the decision to invest in Luleå although a spokesperson for Facebook notes that similar subsidies were available in other locations and it is a small proportion of the estimated 800 million euro investment cost (Crisp, 2012).

It is notable that the presence of the university was not a major factor in the decision of Facebook to locate in the area; however, the availability of skilled staff was seen as an additional benefit. Since the announcement of the data centre's development, there has been a rise in applications for the engineering program at the university, and five other companies have set up data centres nearby (Harding, 2015) illustrating the potential spillover benefits that can be gained.

\subsection{Svalbard, Norway}

Svalbard, Norway is home to some of the most northern communities in the world. As the traditional economies of trapping and mining have declined, so authorities have sought to develop new opportunities. These have embraced science and new technologies, drawing on the locational advantages of the area. The main settlement of Longyearbyen is home to KSAT, providing satellite ground station and earth observation services across the world. Longyearbyen is also the location of the Global Seed Vault, a secure underground storage facility that is intended to provide insurance against both incremental and catastrophic loss of crop diversity held in traditional seed banks around the world. It was located in Svalbard for a number of reasons including access to an internationally-connected airport, its geological conditions including seismic stability, and the 
presence of a stable permafrost in which the vaults can be kept cold even if mechanical cooling systems fail (Global Crop Diversity Trust, 2016).

Some $100 \mathrm{~km}$ further north, at Ny Ålesund, the influence of the unique research environment on the diversification of economic activity can be seen even more clearly. Following a series of major mining accidents, the mines on which Ny Ålesund was based closed in 1963. Since this time the settlement has been developed as an Arctic research station, with the mining company Kings Bay AS supplying the necessary infrastructure. A total of ten nations now operate eleven research facilities in this small settlement that has a year-round population of just thirty persons servicing the needs of the researchers (Kings Bay AS, 2016). One of the early attractions of Svalbard for polar research was its favourable climatic conditions, at 79 degrees north latitude, which reduces the costs of research in the area, and the legacy of an existing infrastructure that had been developed for the mining industry. The development of regular air connections with Longyearbyen, and good quality Internet connectivity in more recent years, have strengthened these locational advantages.

\subsection{Yukon, Canada}

The Yukon is the westernmost, and smallest, of Canada's three federal territories. Adjacent to Alaska, it has a Subarctic climate and is sparsely populated. Almost three-quarters of its population of 35,000 persons live in the capital, Whitehorse. The second largest town, Dawson City, has a population of just 1,300. Famous for its association with the Klondike Gold Rush of the nineteenth century, the economy of the Yukon is still highly dependent on mining, with tourism another important sector. An entrepreneurial economy, with the highest proportion of firms per capita, it is dominated by small businesses (Industry Canada, 2016).

Despite the challenges of dependency on a limited number of small firms, non research and development oriented sectors, and limited accessibility, there are strong examples of innovation activity focusing on the assets of the region. Many of these are supported through the work of the Yukon Research Centre based at Yukon College, the only postsecondary institution in the territory. The research centre focuses on cold climate innovation and technological innovations related to the mining and environmental sectors.

In one example, the college is working with small family-based placer mines to improve the collection of gold from lower-grade ground, finer gold sediments, and past workings. Not only will this bring benefits to local economies, as placer mining is vital in many of the Yukon's 
rural areas, the expertise and technology can also be transferred to the developing world where techniques typically rely on the use of hazardous chemicals. In another example, the college is supporting the development of greenhouses capable of use in cold northern climates, which will help to boost health and food security in more remote areas.

A third example of innovation in practice in the Yukon is to be found in the small settlement of Dawson City. This is the home of Ground Truth, a small company providing initial-stage exploration work for the mining industry. Through in-house development and working with Yukon College, they have developed exploration technologies that are intended to improve the efficiency of identifying commercially exploitable mineral deposits whilst reducing environmental impacts and costs. This includes the development of approaches and technologies that are non grounddisturbing or are adapted for fragile landscapes - technologies that the company is now seeking to market globally. One of the advantages for the company is that with satellite up-link technology, much of the early analysis can be done remotely allowing the firm to market its expertise and approach, as much as the technology itself.

\subsection{Developing a Model of Innovation Particular to the Circumpolar North}

Five key leitmotifs emerge from the examples discussed, which together suggest that innovation practices in the Circumpolar North differ from the standard innovation model.

First, innovation in the Circumpolar North is strongly dependent on the doing, using, interacting mode rather than the science and technology focus on which traditional models of innovation tend to be predicated. This is evident in each of our examples, particularly in the Yukon and Arjeplog, where firms and individuals are adapting pre-existing knowledge to new uses. The importance of the entrepreneurial mindset is similarly evident in each case, with clear examples of this in both the Yukon and Northern Sweden examples, most forcefully in Arjeplog. In the one place where a significant research capacity is present, Svalbard, this tends to be separated from the wider economy, with limited innovation spillovers identified. However, the example of the Yukon demonstrates how connecting local research capacities and local businesses can have positive impacts when areas of interest intersect, particularly where this can enable rapid innovation adoption.

Secondly, each of our examples highlights the significance of local conditions as a key asset on which economic development has been built. This may be in the form of climatic conditions, as in Northern Sweden and 
Svalbard; particular (fragile) environmental conditions, as in the Yukon; or the infrastructure legacy of past industries, as highlighted in Svalbard and Luleå, Sweden. This suggests that when considering the asset base of a region, policy makers may need to take a wider perspective than has traditionally been the case and look beyond research and innovation infrastructures. The physical environment can be as important for the emerging knowledge economy as it has been for the more traditional economy.

A third theme that emerges from the examples is the ongoing role of government support, either through direct subsidies as in Luleå, though public investment in research activities, as in Svalbard, or through ongoing investment in the upgrading of physical and telecommunications infrastructures (Arjeplog and Svalbard). However, our examples in the Yukon and Arjeplog illustrate that activity is not dependent on government support and that a mixed mode is present where individual entrepreneurs, or larger corporations, may lay the ground, with public support following as the initial success of a newly-emergent sector places pressure on existing infrastructures and capacity.

The evidence for the significance of the skills base, as highlighted by writers such as Nathan and Overman (2013), is less clear from our examples. In Arjeplog, the high-level skills on which the cluster was founded were initially imported (Sölvell, 2016), a traditional approach in circumpolar regions. It is only in recent years that local education providers have begun to offer courses related to the skills needs of the industry domain. Similarly in Svalbard, the presence of a university does not necessarily result in an expansion of the skills base of the local labour market, although the potential is there. In the case of the Yukon, however, it is clear that a skilled labour force, able to acquire and adapt new knowledge, is a crucial feature of the innovation landscape. Critically, though, and in a further reflection of the importance of doing, using, interacting innovation models, these skills are not necessarily aligned to the possession of highlevel formal qualifications. Consequently, it appears that the fourth strand of an alternative innovation model would be to value knowledge sets that are wider than our standard measures of educational attainment.

Finally, the examples also emphasize the important role played by experimentation in the development of new domains of activity. In Arjeplog in particular, the new domain of activity has emerged from a classic evolutionary model of economic growth, rather one that was planned and set out in a formal strategy. Similarly, in the Yukon, we see the value of individual initiative and flexible, and often opportunistic, 
working, rather than the constraining mindset of plan-monitor-manage. New paths often start from small beginnings, take time to develop and, crucially, not all initiatives will prove to be successful. Whilst the examples in this article illustrate some success, learning to fail may be just as important in a RIS3 approach.

\section{Conclusions}

Returning to the central question of this article, is the smart specialization approach currently advocated by the European Commission a meaningful concept for circumpolar regions based on the examples highlighted? Elements of it certainly have a clear relevance, notably the emphasis on entrepreneurial discovery processes and the stress on the importance of making choices in where to direct scarce resources. As recognized by Petrov (2016), many circumpolar regions already exhibit signs of specialization, albeit often highly localized, and, proportionately, strong levels of innovation. The examples also illustrate how the legacy of past development paths form the foundations for new path formation. This is a core concept for smart specialization approaches, which argue for the importance of transformational strategies rather than transplant strategies that seek to develop wholly new activities. Successful RIS3 approaches can learn from this blending of new and old.

The RIS3 approach also offers a means for promoting the diversification of the economies of circumpolar regions away from the traditional "pillars," partly through stimulating a debate about potential priority domains, but also through establishing a focus for dialogue and entrepreneurial discovery processes. When supporting the development of collaborative relationships and encouraging the development of purposeful networks as part of an entrepreneurial dynamic, involving the range of actors from across the quadruple helix is critical. The RIS3 approach usefully reminds us that it is not just the resources present within a region that are important, but also how we tap into those resources located elsewhere that can assist in building a critical mass, something which each of examples here have proven adept at doing.

The smart specialization approach can also learn from practices in circumpolar regions. Most notably, this is in taking a more capacious view of what constitutes research and innovation assets. In each of the examples, geographical location and environmental conditions have formed the foundation for developing higher-value activities. Recognizing the value of these assets, rather than seeing them as constraints, has opened up possibilities for innovation-led economic development. When smart 
specialization speaks of comparative advantage, policy makers need to be attuned to the wider potential for this.

Similarly, our examples point to the value of doing, using, and interacting modes of innovation. This is an area that the smart specialization approach does not yet seem to fully embrace, and is a shortcoming in many regions that have a vibrant and entrepreneurial maker-community but a lower proportion of high-technology or research-based firms. Smart specialization approaches could also be more receptive to the value of alternative forms of knowledge. In circumpolar regions this may include knowledge sets such as those held by Indigenous communities, and use these as a basis for forming appropriate innovation paths rather than being led solely by conventional science and technology domains. A move away from overly-privileging linear views of innovation would also open up opportunities to view innovation as a means of supporting the upgrading of firms' positions in a value-chain (and avoiding pressures of downgrading), rather than as a means of simply introducing new products and processes (see Blazek, 2015 for further discussion of this point).

But is the smart specialization approach, even in a modified form, appropriate to circumpolar regions? Would not a focus on entrepreneurship itself be more appropriate? The Yukon and Arjeplog examples both emphasize the importance of entrepreneurship in the development of new opportunities. Both, though, also highlight how accompanying actions across a wider ecosystem have strengthened the examples identified. Similarly, the example of Svalbard offers evidence of the risk that where research investments do occur the area is seen largely as a place where science takes place rather than where innovation happens. An approach based around a more strategic framework, recognizing the particularities of innovation in, of, and for the Circumpolar North could provide the basis for a new model of economic development. This is not about picking winners, but about building the capacity for an innovation-rich ecosystem based on notions of shared leadership. The RIS3 approach, with its emphasis on the entrepreneurial discovery process and the promotion of appropriate institutions, would appear to have much to offer and certainly merits further exploration.

The examples also suggest a further important evolution in the RIS3 concept, which is to question the rationale for promoting innovation. For many strategies, the goal is one of economic growth and the creation of employment, which naturally shapes the actions being promoted. In the case of circumpolar regions, the examples illustrate that other goals are equally significant, notably those directed towards preserving fragile 
environments, providing food security, or maintaining traditional lifestyles. Innovation in these examples is about meeting circumpolar needs rather than simply achieving economic ends. The economic benefits do flow but are secondary features. This serves to highlight the importance for RIS3 strategies to be appropriate to circumstance and not mere imitations of goals and actions developed elsewhere, and would offer a unique perspective on an appropriate model for innovation in the Circumpolar North.

Overall, the concept of smart specialization can have value for circumpolar regions. However, the experiences of peripheral regions and those regions with less-developed research and innovation systems, demonstrate areas where the concept itself needs to evolve, or where policy makers can learn from alternative approaches. Whilst the RIS3 concept cannot provide a blueprint for the development of a particular area, it does offer a useful framework that could add value to the efforts to develop innovation-led strategies in circumpolar regions. In turn, the experience of circumpolar innovation offers many lessons that can add value to the smart specialization approach itself. Not least amongst these is a wider appreciation of the nature of the territorial asset base, a more nuanced view of the innovation process, and, perhaps most significantly, a reprise of the primacy attached to the economic outcomes of the innovation process. As circumpolar innovation moves beyond its infancy it is hoped that these lessons may serve to craft appropriate responses to the innovation challenges faced by remote and peripheral regions.

\section{Author}

Adrian Healy is research associate with the School of Geography and Planning at Cardiff University in Wales.

\section{Acknowledgements}

The author gratefully acknowledges the support received from the European Union's Seventh Framework Programme for research, technological development and demonstration under grant agreement number 320131. A version of this article was first presented at the workshop "Circumpolar Innovation: Making Science and Technology Work for the North." The author gratefully acknowledges the comments and contributions of the participants at this event and the valuable comments of two anonymous referees. 


\section{Notes}

1. The European Union defines Less Developed Regions as those with an average gross domestic product per capita of less than $75 \%$ of the EU average.

\section{References}

Asheim, B., \& Gertler, M. (2005). Regional innovation systems and the geographical foundations of innovation. In J. Fagerberg, D. Mowery, and R. Nelson, R. (Eds), The Oxford Handbook of Innovation (pp. 291-317). Oxford: Oxford University Press.

Asheim, B., Coenen, L., \& Vang, J. (2007). Face-to-face, buzz and knowledge bases: Sociospatial implications for learning, innovation and innovation policy. Environment and Planning C: Government and Policy, 25, 655-670.

Baerenholdt, J. O., \& Aarsaether, N. (2002). Coping strategies, social capital and space European. Urban and Regional Studies, 9(2), 151-165. https://doi. org/10.1177/096977640200900204

Barca, F. (2009). An agenda for a reformed cohesion policy: A place-based approach to meeting European Union challenges and expectations. An independent report prepared at the Request of the European Commissioner for Regional Policy. Brussels: European Commission.

Blazek, J. (2015). Towards a typology of repositioning strategies of GVC/GPN suppliers: The case of functional upgrading and downgrading. Journal of Economic Geography, 16(4): 849-869. https://doi.org/10.1093/jeg/lbv044

Boden, M., Marinelli, E., Haegerman, K., \& Dos Santos, P. (2015). Bridging thinkers and doers: First lessons from the entrepreneurial discovery process in Eastern Macedonia and Thrace. JRC Science and Policy Report. Smart Specialization Policy Brief No.14/2015, Seville.

Capello, R., \& Lenzi, C. (2013). Territorial patterns of innovation and economic growth in European regions. Growth and Change, 44, 195-227.

Coates, K., \& Poelzer, G. (n.d). Arctic innovation. Retrieved from https://www. usask.ca/icngd/publications/reports/Reports-Files/Arctic\%20Innovation Shared\%20Voices\%202014.pdf

Cooke, P. (2001). Regional innovation systems, clusters and the knowledge economy. Industrial and Corporate Change, 10, 945-974.

Cooke, P. (2012). Complex adaptive innovation systems: Relatedness and transversality in the evolving region. Abingdon (UK): Routledge.

Crisp, J. (2012). EU puts $£ 10 \mathrm{~m}$ into Facebook data centres. The Telegraph, 8 April 2012. Retrieved from http://www.telegraph.co.uk/finance/newsbysector/ mediatechnologyandtelecoms/9193135/EU-puts-10m-into-Facebook-datacentres.html 
De Bruijn, P., \& Lagendijk, A. (2005). Regional innovation systems in the Lisbon strategy. European Planning Studies, 13(8), 1153-1172.

Doloreux, D. (2003). Regional ennovation systems in the periphery: The case of the Beauce in Québec (Canada). International Journal of Innovation Management, 07, 67. https://doi.org/10.1142/S1363919603000738

Doloreux, D. and Dionne, S. (2008). Is regional innovation system development possible in peripheral regions? Some evidence from the case of La Pocatière, Canada. Entrepreneurship \& Regional Development, 20(3), 259-283.

Drache, D. (2009). Canada's resource curse: Too much of a good thing. NorteAmérica, 4(1) January-June, 15-53.

Duhaime, G., \& Caron, A. (2015). The economy of the circumpolar Arctic. In S. Glomsrød, G. Duhaime, and I. Aslaksen (Eds), The economy of the north 2015. Oslo: Statistics Norway.

European Commission. (2012). Guide to research and innovation strategies for smart specialization. Brussels: European Commission.

European Commission. (2013). Regulation (EU) No 1303/2013 of the European Parliament and of the Council, 17 December 2013. Official Journal of the European Union L 347/320.

European Commission. (2014). National/regional innovation strategies for smart specialization. Cohesion Policy Fact Sheet. Brussels: DG Regio, March 2014.

Foray, D., David, P. A., \& Hall, B. H. (2011). Smart specialization: From academic idea to political instrument, the surprising career of a concept and the difficulties involved in its implementation. METI Working Paper 2011-001, Ecole Poytechnique Federal de Lausanne.

Foray, D. (2014). Smart specialization: Opportunities and challenges for regional innovation policy. Abingdon (UK): Routledge.

Gertler, M. (2008). Buzz without being there? Communities of practice in context. In A. Amin \& J. Roberts (Eds.), Community, Economic Creativity, and Organization. Oxford: Oxford University Press.

Global Crop Diversity Trust. (2016). Svalbard lobal Seed Vault. Retrieved from https://www.croptrust.org/what-we-do/svalbard-global-seed-vault/ faq-about-the-vault/

Gregory, M. (2013). Inside Facebook's green and clean Arctic data centre. BBC online, 14 June 2013. Retrieved from http://www.bbc.co.uk/news/business-22879160

Harding, L. (2015). The node pole: Inside Facebook's Swedish hub near the Arctic Circle. The Guardian (online version), 25 September 2015. Retrieved from https://www.theguardian.com/technology/2015/sep/25/ facebook-datacentre-lulea-sweden-node-pole

Hausmann, R., \& Rodrik, D. (2003). Economic development as self-discovery. Journal of Development Economics, 72(2), 603-633. 
Hayek, F.A. Von. (1978). Competition as a discovery procedure. In F.A. Von Hayek, New studies in philosophy, politics, economics and the history of ideas (pp. 179-90). Chicago: University of Chicago Press.

Heinen, L. (2005). Impacts of globalization, and the circumpolar north in world politics. Polar Geography, 29(2). Available online 2011. https://doi. org/10.1080/789610127

Huskey, L. (2005). Challenges to economic development: Dimensions of "remoteness" in the North. Polar Geography, 29(2). Available online 2011. https://doi.org/10.1080/789610127

Iacobucci, D. (2014). Designing and implementing a smart specialization strategy at a regional level. Scienze Regionali, 13(1), 107-126.

Industry Canada. (2016). Key small business statistics-June 2016. Retrieved from https://www.ic.gc.ca/eic/site/061.nsf/eng/h_03018.html\#table1-1-1

Iskanius, P. (n.d). Operational platform for the northern research and innovation. Retrieved from http://www.kotu.oulu.fi/projektit/tiim2011/TIIM\%20full\%20 paperit/Proceedings/Day\%202/3rd\%20parallel/B31.pdf

Kinnander, O. (2011). In Sweden's frigid north, car testing is hot. Bloomberg Business Week, April 11. Retrieved from http://www.bloomberg.com/news/ articles/2011-04-07/in-swedens-frigid-north-car-testing-is-hot

Kirzner, I. M. (1997). Entrepreneurial discovery and the competitive market process: An Austrian approach. Journal of Economic Literature, 35(1), 60-85.

Kaul, I. (2002). Challenges of human development in the Arctic. New York: United Nations Development Programme. Retreived from http://www.arcticparl. org/files/static/conf5 kaul.pdf

Kings Bay AS. (2016). Research stations in Ny Ålesund. Retrieved from http:// kingsbay.no

Kroll, H. (2015a). Efforts to implement smart specialization in practice: Leading unlike horses to the water. European Planning Studies, 23(10), 2079-2098. https://doi.org/10.1080/09654313.2014.1003036

Kroll, H. (2015b). Weaknesses and opportunities of RIS3-type policies: Seven theses. Kahlsruhe: Fraunhofer ISI.

Larsen, J. N. (2016). Polar economics: Expectations and real economic futures. The Polar Journal, 6(1), 1-10. https://doi.org/10.1080/2154896X.2016.1171005

Larsen, J. N., \& Fondahl, G. (2015). Arctic human development report: Regional processes and global linkages. Copenhagen: Nordic Council of Ministers.

Mazzucato, M. (2013). The entrepreneurial state: Debunking public vs private sector myths. London: Anthem.

McCann, P., \& Ortega-Argilés, R. (2011). Smart specialization, regional growth and applications to EU cohesion policy. Economic Geography Working Paper 2011, Faculty of Spatial Sciences, University of Groningen. 
Mehlum, H., Moene, K., \& Torvik, R. (2005). Cursed by resources or institutions? Working Paper Series No. 10/2005, 23p, Department of Economics, Norwegian University of Science and Technology.

Milazzo, E. (n.d). Opportunities and challenges: Economic, social and political impacts of climate change in the Arctic. Undated blog retrieved from https://accelfellowship. wordpress.com/opportunities-and-challenges-economic-social-and-politicalimpacts-of-climate-change-in-the-arctic/

Morgan, K. (2016). European innovation ecosystems: Good governance and effective business support for smart specialization. Presentation to Committee of the Regions/European Commission Joint Conference, 26 January, Brussels.

Morgan, K., \& Nauwelaers, C., eds. (1999). Regional innovation strategies: The challenge for less favoured regions. London: Stationery Office.

Nathan, M., \& Overman, H. (2013). Agglomeration, clusters, and industrial policy. Oxford Review of Economic Policy, 29(2), 383-404. https://doi.org/10.1093/oxrep/ grt019

Orange, R. (2011). Facebook to build server farm on edge of Arctic Circle. The Telegraph, 26 Oct 2011.

Oughton, C., Landabaso, M., \& Morgan, K. (2002). The regional innovation paradox: Innovation policy and industrial policy. Journal of Technology Transfer, 27, 97-110.

Overman, H. (2012). Investing in the UK's most successful cities is the surest recipe for national growth. Blogs.LSE.AC.UK, January 26. Retrieved from http:// eprints.lse.ac.uk/44073/

Petrov, A.N. (2015). Arctic's emerging 'other' economies: Technology, knowledge and culture in the new Arctic economy. In S. Glomsrød, G. Duhaime, \& I. Aslaksen (Eds.), The economy of the north 2015. Oslo: Statistics Norway.

Petrov, A.N. (2016). Exploring the Arctic's 'other economies': Knowledge, creativity and the new frontier. The Polar Journal, 6(1), 51-68. https://doi.org/1 $\underline{0.1080 / 2154896 X .2016 .1171007}$

Riabova, L. (2010). Community viability and wellbeing in the circumpolar north. In L. Heinninen \& C. Southcott (Eds). Globalization and the circumpolar north. Fairbanks: University of Alaska Press.

Rodríquez -Pose, A. (2013). Do institutions matter for regional development? Regional Studies, 47, 1034-1047.

Sölvell, Ö. (2016). Arjeplog winter car testing: Emergence of a cluster. Center for Strategy and Competitiveness, Stockholm School of Economics.

Strambach, S., \& Klement, B. (2012). Cumulative and combinatorial microdynamics of knowledge: The role of space and place in knowledge integration. European Planning Studies, 20, 1843-1866.

Tödling, F., \& Trippl, M. (2005). One size fits all? Towards a differentiated regional innovation policy approach. Research Policy, 34, 1203-1219. 
Tödtling, F., \& Trippl, M. (2013). Transformation of regional innovation systems: From old leagacies to new development paths. In P. Cooke (ed.), Reframing Regional Development (pp. 297-317). London: Routledge.

Torre, A., \& Wallet, F. (2013). Innovation and the governance of rural territories. In E. Coudel et al. (Eds.), Regional innovation systems in agriculture and food: How to go towards more sustainability. Wageningen: Wageningen Academic Publishers.

Trippl, M., Zukauskaite, E., Healy, A., \& Marques, P. (2016). Smart specialization for regional innovation work, Package 5, Deliverable 5.2. Smart Specialization Working Paper. June 2016. Cardiff University, UK.

Weber, K.M., \& Rohracher, H. (2012). Legitimising research, technology and innovation policies for transformative change. Combining insights from innovation systems and multi-level perspectives in a comprehensive 'failures' framework. Research Policy, 41, 1037-1047.

Wilson, E., \& Stammler, F. (2016). Beyond extractivism and alternative cosmologies: Arctic communities and extractive industries in uncertain times. The Extractive Industries and Society, 3, 1-8. https://doi.org/10.1016/j.exis.2015.12.001

Wolfe, D. (2009). 21 ${ }^{\text {st }}$ Century Cities in Canada: The geography of innovation. Ottawa: The Conference Board of Canada.

Wolfe, D. (2014). The staple theory and Canada's innovation challenge. In J. Stanford (Ed.), The Staple Theory @ 50: Reflections on the Lasting Significance of Mel Watkins' "A Staple Theory of Economic Growth." Ottawa: Canadian Centre for Policy Alternatives. 